\title{
THE NUTRITIVE VALUE OF HUMAN PLASMA FOR THE RAT
}

\author{
By D. M. HEGSTED, J. M. McKibBIN, AND F. J. STARE \\ (From the Department of Nutrition, Harvard School of Public Health, and \\ the Department of Biological Chemistry, Harvard Medical School, Boston)
}

(Received for publication February 21, 1944)

Extensive studies by Madden and Whipple (1) on the value of various proteins in the regeneration of plasma proteins in dogs have demonstrated a marked superiority of plasma proteins over all other protein sources tested. Similar data by different technics have been obtained by Weech (2) and by Melnick, Cowgill, and Burack (3), although the latter group concluded that the differences between serum, casein, and lactalbumin were not significant. It thus appears that plasma proteins may be considered to be of high biological value as measured by these technics. In measurements of the hematopoietic values of certain proteins for rats, Orten and Orten (4) found that beef serum was much less effective than lactalbumin, and when fed at a level which supplied 18 per cent of protein in the diet, supported only very poor growth. This is in marked contrast to the above results and might be unexpected if one considers the plasma proteins as a labile source of protein for other body functions.

Although plasma proteins are not used as a source of human food, their nutritive value may be of considerable importance. Patients are often maintained for some time with plasma as the chief if not the sole source of protein. Protein appears to be of primary importance in many of these patients, and the huge losses of nitrogen after various types of injury have recently been stressed (5). Recent data also emphasize the very rapid response of the body to amino acid deficiencies, negative nitrogen balances being obtained within a few hours $(6,7)$. The implication of these combined facts is that if patients are unable to take adequate diets, the intravenous nutrients, especially protein, should be as adequate as possible.

The studies reported in this paper were undertaken to determine the nutritive value of human plasma proteins for the young rat and have shown that isoleucine is the chief deficiency of these proteins for this animal.

\section{EXPERIMENTAL}

Young male weanling rats, weighing 30 to 35 grams, were used in all of these studies. They were placed immediately upon a purified ration containing the appropriate protein supplement, corn oil 4 per cent, salt mixture 4.7 per cent, ${ }^{1}$ all of the crystalline vitamins ${ }^{2}$ in excess of requirements (8) and sucrose to make 100 per cent. Haliver oil was fed by dropper twice weekly. For comparative purposes, various levels of casein were fed as the sole source of protein. Dried plasma ${ }^{3}$ was fed to supply 18 per cent of protein and when amino acid or protein supplements were fed with the plasma, it was correspondingly decreased so that the total protein $(\mathrm{N} \times 6.25)$ was 18 per cent of the ration.

Two experiments were run to determine the supplementary effect of casein, zein, and gelatin on plasma proteins. As shown in Table I, very

TABLE I

The value of various proteins in supplementing human plasma in rat-growth experiments

\begin{tabular}{|c|c|c|c|}
\hline Kind and amount of protein & $\begin{array}{c}\text { Num- } \\
\text { ber of } \\
\text { rats }\end{array}$ & Duration & $\begin{array}{l}\text { Gain } \\
\text { per } \\
\text { day }\end{array}$ \\
\hline $\begin{array}{l}12 \text { per cent casein } \\
15 \text { per cent casein } \\
18 \text { per cent casein } \\
18 \text { per cent plasma } \\
3 \text { per cent casein }+15 \text { per cent plasma } \\
6 \text { per cent casein }+12 \text { per cent plasma } \\
9 \text { per cent casein }+9 \text { per cent plasma } \\
3 \text { per cent zein }+15 \text { per cent plasma } \\
6 \text { per cent zein }+12 \text { per cent plasma } \\
9 \text { per cent zein }+9 \text { per cent plasma } \\
3 \text { per cent gelatin }+15 \text { per cent plasma } \\
6 \text { per cent gelatin }+12 \text { per cent plasma }\end{array}$ & $\begin{array}{l}\mathbf{5} \\
\mathbf{5} \\
\mathbf{8} \\
\mathbf{8} \\
\mathbf{8} \\
\mathbf{8} \\
\mathbf{3} \\
\mathbf{3} \\
\mathbf{3} \\
\mathbf{3} \\
\mathbf{3} \\
\mathbf{3}\end{array}$ & $\begin{array}{l}\text { days } \\
33 \\
33 \\
16 \text { and } 33^{*} \\
16 \text { and } 33^{*} \\
16 \text { and } 33^{*} \\
16 \text { and } 33^{*} \\
16 \\
16 \\
16 \\
16 \\
16 \\
16\end{array}$ & $\begin{array}{l}\text { grams } \\
2.21 \\
2.53 \\
3.33 \\
0.92 \\
1.39 \\
1.87 \\
2.0 \\
1.25 \\
1.41 \\
1.67 \\
1.08 \\
1.12\end{array}$ \\
\hline
\end{tabular}

* Two experiments of 33 and 16 days' duration gave essentially the same result.

1 Salts IV (J. Biol. Chem., 1941, 138, 459) 4 grams and $\mathrm{K}_{2} \mathrm{HPO}$, 0.7 grams.

2 We are indebted to Merck and Co. for furnishing the crystalline vitamins used.

- We are indebted to Mr. E. B. Carter of Abbott Laboratories for securing dried plasma for these investigations. The plasma so obtained was contaminated and not suitable for human use. It was secured from the Army Medical Supply Office. 
poor growth was obtained with plasma alone. Relatively high levels of casein are required to improve the rate of growth, and gelatin and zein were much less effective than casein. It thus appeared that none of these proteins was a rich source of the amino acids which are low in plasma.

Studies on the supplementary action of amino acids are shown in Table II. In these studies, all of the animals were first fed the ration containing only plasma as a source of protein for 3 to 5 days. They were then divided into comparable groups and fed the experimental ration. The growth obtained with 18 per cent casein is usually about 3 grams per day. In Experiments I and II, the growth obtained with plasma supplemented with a mixture of amino acids was good and approached that obtained with casein. Further studies in Experiments III and IV show that the deficiency in human plasma proteins is due chiefly to a lack of sufficient isoleucine. Apparently, 0.5 per cent additional $\mathrm{dl}$ isoleucine is about as effective as is 1 per cent. Since only small numbers of animals have been used (be- cause of the expense of amino acid supplementation), the differences between the various groups receiving isoleucine and those receiving isoleucine plus other amino acids are of doubtful significance, although the further addition of arginine has always given somewhat better growth than isoleucine alone.

\section{DISCUSSION}

Analyses for 12 amino acids in serum proteins have been presented by Block and Bolling (9). A calculation of the amount of these acids which would be supplied in the ration when 18 per cent of plasma protein is used shows that all of the essential amino acids would be present in amounts equal to those reported as minimal for the growing rat (10). A similar comparison of the data given for casein indicates that plasma proteins are as high or higher than casein in all of the essential amino acids with the one exception of isoleucine. The isoleucine content of plasma proteins is given as 3.2 per cent whereas casein is reported to contain 5.1 per cent. Plasma pro-

The effect of amino acid supplements on the nutritive value of plasma in rat-growth experiments

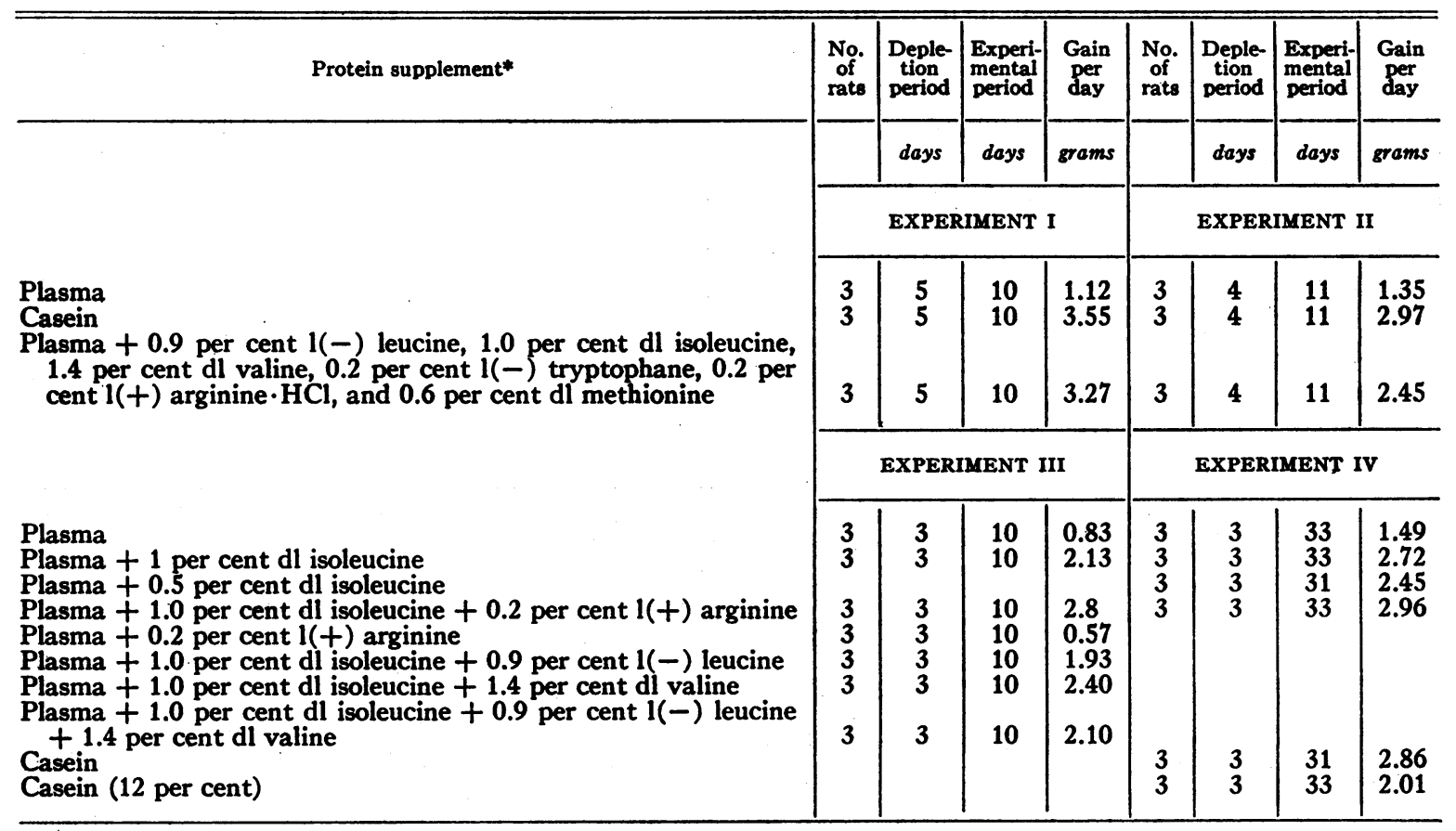

* All rations adjusted to contain 18 per cent protein (total $\mathrm{N} \times 6.25$ ). 
teins should supply, therefore, approximately 0.57 per cent of isoleucine in a ration if fed at an 18 per cent level. Unpublished data from this laboratory obtained by microbiological assays (11) indicate an isoleucine content between 2.4 and 2.8 per cent for human plasma proteins. On the basis of these figures, an 18 per cent plasma protein ration would contain from 0.43 to 0.5 per cent isoleucine.

As far as we are aware, plasma proteins are unique among those so far investigated in that they are primarily low in isoleucine. It will be of interest to determine whether this is true of the plasma proteins from various species. According to recent evidence (12) isoleucine is also an essential amino acid for the adult human, but the quantitative requirement of the adult of no species is yet known. Thus the significance of these findings in relation to the problem of intravenous nutrition must await further investigation.

Accepting an average figure of 2.6 as the percentage of isoleucine in plasma proteins, and that only the one isomer is active (13), the isoleucine requirement of the rat would probably be near 0.7 per cent, since the addition of 0.5 per cent of $\mathrm{dl}$ isoleucine to the plasma proteins appears to give a near maximum response.

\section{CONCLUSION}

Human plasma proteins are inadequate as the sole source of protein for the growing rat. A low content of isoleucine is the primary amino acid deficiency. A supplement of 0.5 per cent $\mathrm{dl}$ isoleucine gives a near maximum response.

\section{BIBLIOGRAPHY}

1. Madden, S. C., and Whipple, G. H., Plasma proteins: their source, production and utilization. Physiol. Rev., 1940, 20, 194.

2. Weech, A. A., The significance of the albumin fraction of serum. Bull. New York Acad. Med., 1939, 15, 63.

3. Melnick, D., Cowgill, G. R., and Burack, E., The influence of diet upon the regeneration of serum protein. II. The potency ratios of serum protein, lactalbumin and casein, and the effect of tissue protein catabolism on the formation of serum protein. J. Exper. Med., 1936, 64, 897.

4. Orten, A. U., and Orten, J. M., Comparative hematopoietic values of certain dietary proteins. Fed. Proc., 1943, 2, 67.

5. Editorial, Postoperative nitrogen loss. J. A. M. A., 1943, 121, 346.

6. Holt, L. E., Jr., Albanese, A. A., Brumback, J. E., Jr., Kajdi, C., and Wangerin, D. M., Nitrogen balance in experimental tryptophane deficiency in man. Proc. Soc. Exper. Biol. and Med., 1941, 48, 726.

7. Rose, W. C., Haines, W. J., and Johnson, J. E., The rôle of the amino acids in human nutrition. J. Biol. Chem. 1942, 146, 683.

8. Hegsted, D. M., McKibbin, J. M., and Stare, F. J., The effect of atabrine in choline deficiency in the young rat. J. Nutrition, 1944, 27, 149.

9. Block, R. J., and Bolling, D., The Determination of the Amino Acids. Burgess Publishing Co., Minneapolis, Minnesota, 1942.

10. Rose, W. C., The physiology of amino acid metabolism. Proc. Inst. Med. Chicago, 1938, $12,98$.

11. Hegsted, D. M., The amino acid requirements of Lactobacillus arabinosus 17-5. J. Biol. Chem., 1944, 152, 193.

12. Rose, W. C., Haines, W. J., Johnson, J. E., and Warner, D. T., Further experiments on the rôle of the amino acids in human nutrition. J. Biol. Chem., 1943, $148,457$.

13. Rose, W. C., The nutritive significance of the amino acids. Physiol. Rev., 1938, 18, 109. 